\title{
Effects of short-term starvation on composition and metabolism of larval Antarctic krill Euphausia superba
}

\author{
Bettina Meyer ${ }^{1, *}$, Bernadette Oettl ${ }^{1,2}$ \\ ${ }^{1}$ Alfred Wegener Institute for Polar and Marine Research, Scientific Division Biological Oceanography, Handelshafen 12 , \\ 27570 Bremerhaven, Germany \\ ${ }^{2}$ Present address: Marine Zoology, University of Bremen, PO Box 3304 40, 28334 Bremen, Germany
}

\begin{abstract}
Metabolic rates and elemental and biochemical composition of Furcilia IV (FIV) larvae of Euphausia superba were studied during $12 \mathrm{~d}$ of starvation at the onset of winter in the Bellingshausen Sea. This time of the year may be a critical period in the krill life cycle because their larvae must switch from feeding on summer phytoplankton blooms to winter ice algae. FIV utilized mainly lipids overall, but also protein during the second half of the $12 \mathrm{~d}$ period. After $6 \mathrm{~d}$ of starvation most of the larvae lost half of their body C. Body lipid content decreased from 12.7 to $1.5 \%$ of dry mass (DM), whereas protein fell from 32.7 to $25.8 \%$ of DM. Respiration rates decreased from 1.3 to $0.7-0.8 \mu \mathrm{l} \mathrm{O}{ }_{2}(\mathrm{mg} \mathrm{DM})^{-1} \mathrm{~h}^{-1}$ in the first $3 \mathrm{~d}$, after which they remained roughly constant. These rates correspond to $\mathrm{C}$ losses of 2.7 and $2.0 \%$ body $\mathrm{C} \mathrm{d}^{-1}$ respectively. Excretion rates decreased from 0.04 to $0.02 \mu \mathrm{g} \mathrm{NH}_{4}(\mathrm{mg} \mathrm{DM})^{-1} \mathrm{~h}^{-1}$ until the middle of the starvation period and then rose to $0.05 \mu \mathrm{g}$ $\mathrm{NH}_{4}(\mathrm{mg} \mathrm{DM})^{-1} \mathrm{~h}^{-1}$ by the end, which is probably related to the increase in protein breakdown. Based on these losses of body $\mathrm{C}$ and lipid, the FIV larvae may pass their point of no return, where they lose their ability to recover from nutritional stress, after $6 \mathrm{~d}$.
\end{abstract}

KEY WORDS: Antarctic krill $\cdot$ Euphausia superba $\cdot$ Larval krill $\cdot$ Starvation

\section{INTRODUCTION}

The Antarctic krill Euphausia superba (hereafter krill) plays a key role in the ecosystem of the Southern Ocean and occupies a central place in commercially valuable resources. Publications during the last decade have shown that the population size of krill seems to be driven by recruitment rather than by predation pressure on postlarvae, and that recruitment is likely related to seasonal sea ice dynamics (Smetacek et al. 1990, Siegel \& Loeb 1995, Quetin et al. 1996, Quetin \& Ross 2003, Atkinson et al. 2004). Several studies have shown that larval and adult krill have fundamentally different overwintering mechanisms. Adults are able to survive over $200 \mathrm{~d}$ (i.e. the entire winter) without food by using their lipid reserves and reducing their metabolic rates (e.g. Quetin \& Ross 1991, Atkinson et al. 2002) and it is assumed that they shrink during long starvation periods (e.g. Ikeda \& Dixon 1982). Larval krill have low lipid reserves (Hagen et al. 2001) and thus might not be able to tolerate long starvation periods. Further, adults may switch to benthopelagic (Kawagushi et al. 1986) or carnivorous feeding (Hopkins et al. 1993, Atkinson et al. 2002), whereas larval krill have to feed on ice algae to survive (e.g. Daly 1990, Hagen et al. 2001, Frazer et al. 2002, Meyer et al. 2002, Quetin et al. 2003).

Starvation resistance is thus important in respect to this critical autumn-winter transition period for larval krill. Quetin \& Ross (2003) describe 2 critical periods of larval krill survival in their first year of life. The first is after developing into the first feeding stage (Ross \& 
Quetin 1989); the larvae have to find adequate food within 10 to $14 \mathrm{~d}$ to survive, if not, they reach their 'Point of no Return' (PNR). The second critical period is during the first winter when larvae must feed to grow but food in the water column is scarce. The PNR is the time after which a larva loses its capability to recover from nutritional stress (Anger \& Dawirs 1981). After passing the PNR, starved and subsequently fed larvae are unable to recover from the effects of prolonged starvation, they fail to develop normally and die. Ross \& Quetin (1991) found a mean survival time for Furcilia IV (FIV), FV and FVI during starvation of 29, 59 and $69 d$, respectively. This finding suggests that older larvae survive longer starvation periods than younger stages, but no stage could survive a winter without food, unlike the adults. However, the time taken to starve to death and the PNR are not the same and we have no information on how starvation affects the elemental and biochemical composition of furcilia and know little of how starvation affects their metabolic rates (Frazer et al. 2002, Meyer et al. 2002).

Here we measure elemental and biochemical composition as well as metabolic rates in FIV larvae of Euphausia superba during a short-term starvation period of $12 \mathrm{~d}$. Short-term periods of starvation for larvae are expected to occur at the onset of sea ice formation in the Antarctic autumn. During this phase phytoplankton biomass in the water column decreases, while at the same time remnant concentrations are incorporated into the growing sea ice (Thomas \& Dieckmann 2003). At this stage of sea ice formation, phytoplankton or ice algae are not accessible to larger grazers such as larval krill. Only later in the season will a bottom community develop in the sea ice, representing an additional food source. This study provides further insight into the survival mechanisms of E. superba furcilia larvae in the Southern Ocean ecosystem.

\section{MATERIALS AND METHODS}

Investigation area and sampling. In austral autumn (April to May 2001) during the Expedition ANT XVIII/5b to the eastern Bellingshausen Sea (66 to $71^{\circ} \mathrm{S}$ and 58 to $86^{\circ} \mathrm{W}$ ) sampling was carried out on board RV 'Polarstern'. The experimental larvae were collected on the first transect of the cruise at Stn $301\left(66^{\circ} 35.50^{\prime} \mathrm{S}\right.$, $71^{\circ} 56.49^{\prime} \mathrm{W}$ ). The station was located near the shelf break, over the continental slope (Fig. 1). A detailed description of all sampling locations of the expedition and the hydrography is given by Pakhomov et al. (2004). The integrated chl a profiles in the upper $200 \mathrm{~m}$ show a slightly increasing concentration towards the coast from $50 \mathrm{mg} \mathrm{m}^{-2}$ at Stn 301 to $80 \mathrm{mg} \mathrm{m}^{-2}$ at Stn 305

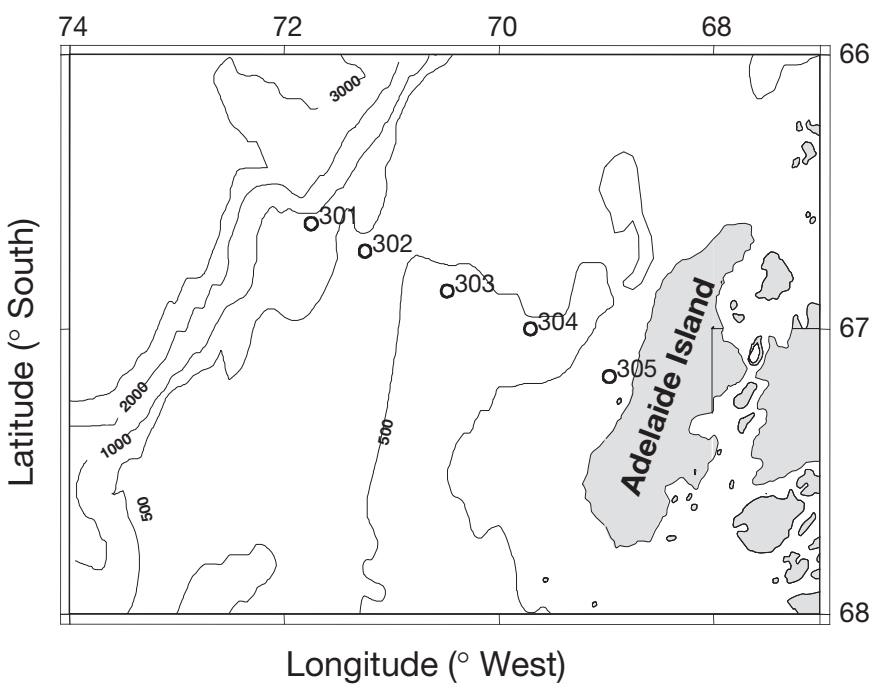

Fig. 1. Location of the first transect (from Stns 301 to 305) with Sampling Stn 301, near the shelf break, over the continental slope

(Fig. 1, Brichta \& Belem 2002). In the upper $200 \mathrm{~m}$ the temperature ranged between 0 to $1^{\circ} \mathrm{C}$ (Strass et al. 2002).

The larvae were collected with a Rectangular Midwater Trawl (RMT 1). One fraction of freshly caught larvae ( $t_{0}$-group) was immediately frozen at $-80^{\circ} \mathrm{C}$ for later determination of body length, elemental composition ( $\mathrm{C}$ and $\mathrm{N}$ ), total body protein and lipid content, at the Alfred Wegener Institute, Germany. A second fraction of freshly caught larvae were used to measure oxygen uptake rates, ammonium excretion and feeding rates. A third fraction was used for the starvation experiment, being transferred to a plastic container filled with 501 of natural seawater and stored at room temperature $\left(0^{\circ} \mathrm{C}\right)$. There, the larvae were sorted by stage under a binocular microscope following Fraser (1936), and the dominant stage, FIV, was used for the starvation experiment.

Experimental set-up. For the starvation experiment 300 FIV were incubated individually in $150 \mathrm{ml}$ of $0.2 \mu \mathrm{m}$ filtered seawater. The animals were checked daily for mortality, moulting and general fitness. The water was changed every second day. Moulted animals were frozen. After 3, 6, 9, and $12 \mathrm{~d}$ of starvation, subsamples were frozen at $-80^{\circ} \mathrm{C}$ for future analysis of body length, elemental composition ( $\mathrm{C}$ and $\mathrm{N}$ ), total protein and total lipid. Another fraction of larvae was used for measuring oxygen uptake and ammonium excretion rates. The intermoult period (IMP) was calculated by using the reciprocal of the moult frequency during the first $3 \mathrm{~d}$ of the experiment, since the growth of krill measured in filtered seawater over the first $3 \mathrm{~d}$ after capture reflects in situ conditions (after Nicol et al. 1992 and Nicol 2000). 
Morphometrics, elemental and biochemical composition. The body length (BL) of larvae was measured from the front of the eyes to the tip of the telson under a stereomicroscope. From the freshly caught larvae 52 animals were used for the correlation of dry mass (DM) to BL. For DM and body $\mathrm{C}$ and $\mathrm{N}$ content determination, larvae were analysed individually. After lyophilization for $48 \mathrm{~h}$ the larvae were weighed and elemental composition was analysed as described in Meyer et al. $(2002,2003)$. In the starvation experiment 3 to 7 replicates were analysed from each sampling day $(0,3,6,9,12)$.

Total protein was measured by homogenising 1 larval krill in $4 \mathrm{ml}$ of $5 \%$ trichloroacetic acid on crushed ice using a Branson Sonifer B15 cell disrupter. After centrifugation at $6000 \mathrm{rpm}(5000 \times g)$ for $10 \mathrm{~min}$ the remaining pellet was used for protein analysis after Lowry et al. (1951), with bovin serum albumin as a standard. From the freshly caught larvae, 20 replicates were analysed in FIV, and in the starvation experiment, 5 replicates were analysed from each sampling day.

For total lipid determination 10 FIV larvae were pooled for one analysis. Only in the $t_{0}$ group were there enough larvae to analyse 3 replicates. After lyophilization for $48 \mathrm{~h}$, samples were weighed and the total lipid was extracted with dichloromethane/methanol (DCM: $\mathrm{MeOH}, 2: 1$ by volume), and determined gravimetrically (Hagen 2000).

Feeding experiments. Feeding experiments were conducted using natural seawater from a depth of 10 to $20 \mathrm{~m}$ because chl a concentration at this depth was in the upper range of values measured in the mixed layer (Strass et al. 2002). The incubation water was collected with a rosette sampler fitted with 24 Niskin bottles (12 l) fitted with teflon springs. The water was immediately drawn through silicon tubing into a $50 \mathrm{l}$ container. Two replicate subsamples (1 l l) were siphoned for chl a analysis to measure the concentration of the autotrophic biomass. These samples were filtered onto Whatman GF/F filters, sonicated on ice for $30 \mathrm{~s}$ with $10 \mathrm{ml}$ of $90 \%$ aqueous acetone and centrifuged $(700 \times g)$ for $3 \mathrm{~min}$. The supernatant was used to measure chl $a$ with a Turner 700D fluorometer (Wright et al. 1997).

For the feeding experiments the food medium was transferred through silicon tubing from the mixed contents of the $50 \mathrm{l}$ container to $2.4 \mathrm{l}$ bottles. Each experiment with freshly caught larvae was comprised of 6 replicate bottles each with 5 FIV larvae and 3 controls without. Bottles were incubated on a plankton wheel $(0.5 \mathrm{rpm})$ in the dark for $24 \mathrm{~h}$ at $0^{\circ} \mathrm{C}$. At the end of the experiment, animals were checked for mortality and subsamples were siphoned for chl a analyses as described above.
Calculation of feeding rates. Clearance rates on the total phytoplankton biomass were calculated from Frost's (1972) equation modified by Båmstedt et al.

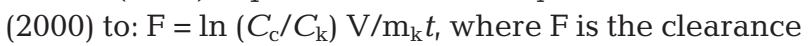
rate $\left(\mathrm{ml} \mathrm{mg}^{-1}\right.$ body $\left.\mathrm{C} \mathrm{h}^{-1}\right), C_{\mathrm{c}}$ the final concentration in the control, $C_{\mathrm{k}}$ is the final concentration in the incubation bottles grazed by the larvae, $\mathrm{V}$ is the experimental volume $(\mathrm{ml}), \mathrm{m}_{\mathrm{k}}$ is the body mass (mg C) of larvae, and $t$ is the experimental duration (h).

Ingestion rates of the total autotrophic biomass were calculated as the product of the clearance rate on the total algal biomass $\left(\mathrm{ml} \mathrm{mg}^{-1}\right.$ larvae body $\mathrm{C} \mathrm{h}^{-1}$ ) and its $\mathrm{C}$ concentration in the final control ( $\mathrm{mg}$ carbon $\mathrm{ml}^{-1}$ ). Ingestion rates were then expressed as a daily $\mathrm{C}$ ration under the assumption that larval feeding rates reflected the daily average rate. The measured chl $a$ concentration was converted to $\mathrm{C}$ equivalents using a C:chl a ratio of 50. The usefulness of this ratio is described in detail in Meyer et al. (2003).

Metabolic rate measurements. For measuring oxygen uptake and ammonium excretion rates, 2 FIV larvae were incubated in sealed $0.15 \mathrm{l}$ bottles filled with filtered seawater $(0.2 \mu \mathrm{m}$ pore size) for $24 \mathrm{~h}$ at an in situ temperature of 0 to $0.5^{\circ} \mathrm{C}$. The respiration and ammonium measurements were made with freshly caught and starved larvae, there were 10 and 3 replicates respectively, and 4 controls (without larvae) were performed. Dissolved oxygen was determined by Winkler titration using a 716 DMS Titrino (METROHM). Ammonium was analysed photometrically with the phenol-hypochlorite method after Solorzano (1969).

Statistics. Analysis of variance was performed to detect significant differences between parameters measured in freshly caught larvae ( $t_{0}$-group) and after $3,6,9$, and $12 \mathrm{~d}$ of starvation. Using the SPSS ${ }^{\mathrm{TM}}$ software package for PC, a 1-way ANOVA (Model I) was calculated and the Holm-Sidak post hoc test was applied for multiple comparisons. For all correlations presented a Type I regression was used.

\section{RESULTS}

\section{Abundance of krill larvae and environmental conditions}

The highest larval abundance was found near the shelf break, over the continental slope with a mean total larval density of 19444 ind. $\mathrm{m}^{-2}$, compared to the shelf region with a mean abundance of 4174 ind. $\mathrm{m}^{-2}$ (Pakhomov et al. 2004). At our sampling station, the stage composition ranged from Calyptopis III (CIII) to Furcilia VI (FVI), with FIV as the most abundant stage $(42 \%)$, followed by FIII $(26 \%)$, FII $(15 \%)$, FV $(6 \%)$, FVI $(5 \%)$, FI $(2 \%)$ and CIII $(1 \%)$. Larvae 
distribution and abundance during the whole cruise is described by Pakhomov et al. (2004). During the expedition in the eastern Bellingshausen Sea surface values of chl a ranged from 0.1 to $2.7 \mathrm{\mu g} \mathrm{l}^{-1}$ with a sharp decrease below $60 \mathrm{~m}$ depth. The highest values were restricted over the shelf (Brichta \& Belem 2002).

\section{IMP, elemental and biochemical composition}

The in situ IMP of FIV larvae was $15.5 \pm 1.1 \mathrm{~d}$ and the mortality rate $0.63 \pm 0.1 \% \mathrm{~d}^{-1}$. Survival averaged $57 \%$ during the $12 \mathrm{~d}$ of starvation and the daily mortality rate rose to an average of $6.7 \pm 4.9 \%$. The regression of DM (mg) on BL $(\mathrm{mm})$ in freshly caught larvae is: FIV: $\log _{10}(\mathrm{DM})=2.7 \log _{10}(\mathrm{BL})-2.7\left(\mathrm{r}^{2}=0.70, \mathrm{p}<\right.$ $0.001, \mathrm{n}=52$ ), and their daily $\mathrm{C}$ ration ranged between 12 and $14 \%$ of body $\mathrm{C}$ at a food concentration from 63 to $86 \mu \mathrm{gCl}^{-1}$.

The mean loss of body $\mathrm{C}$ and $\mathrm{N}$ from the initial values was highest after $9 \mathrm{~d}$ of starvation (49 and $37 \%$ respectively, Table 1). After $12 \mathrm{~d}$ of starvation, DM and elemental composition were significantly different $(p<$ 0.05) than the values of freshly caught larvae (Fig. 2). After $9 \mathrm{~d}$ of starvation only the body $\mathrm{C}$ content showed a significant difference to the $t_{0}$-group $(\mathrm{p}<0.05)$. The $\mathrm{C}$ content declined faster than the $\mathrm{N}$ content, suggesting a preferential utilization of energy rich lipids; this is also reflected in the decline of the C:N mass ratio during starvation (Fig. 2b-d). Body lipid content decreased from 12.7 to $1.5 \%$ of $\mathrm{DM}$, whereas protein fell from 32.7 to $25.8 \%$ of DM (Fig. 3).

\section{Metabolic rates}

The oxygen uptake rates decreased from $1.3 \mu \mathrm{lO}_{2}$ $\mathrm{mgDM}^{-1} \mathrm{~h}^{-1}$ in the $t_{0}$-group to 0.7 after $6 \mathrm{~d}$ of starvation and remained almost constant until the end of the experiment (Fig. 4a). Ammonium excretion decreased from 0.04 to $0.02 \mu \mathrm{gNH}_{4} \mathrm{mgDM}^{-1} \mathrm{~h}^{-1}$ until Day 6 of starvation and then rose to above the initial rates (Fig. 4b). The excretion rates correspond to a daily $\mathrm{N}$

Table 1. Euphausia superba, Furcilia IV larvae: percentage decrease of dry mass $(\mathrm{DM})$, carbon $(\mathrm{C})$, and nitrogen $(\mathrm{N})$ after 6,9 , and $12 \mathrm{~d}$ of starvation to the initial values of freshly caught larvae. Minimal (Min), maximal (Max) and mean values for each day

\begin{tabular}{|c|c|c|c|c|c|c|c|c|c|c|}
\hline $\begin{array}{l}\text { Days of } \\
\text { starvation }\end{array}$ & $\mathrm{n}$ & Min & $\begin{array}{l}\text { DM } \\
\text { Max }\end{array}$ & Mean & Min & $\begin{array}{c}\mathrm{C} \\
\text { Max }\end{array}$ & Mean & Min & $\begin{array}{c}\mathrm{N} \\
\text { Max }\end{array}$ & Mean \\
\hline 6 & 12 & 6.2 & 36.2 & 18.3 & 11.7 & 39.6 & 19.9 & 7.5 & 30.1 & 13.4 \\
\hline 9 & 12 & 11.4 & 48.5 & 35.7 & 33.6 & 59.9 & 48.9 & 16.7 & 45.0 & 37.2 \\
\hline 12 & 16 & 20.0 & 53.7 & 37.0 & 24.7 & 59.3 & 44.3 & 14.5 & 50.8 & 34.0 \\
\hline
\end{tabular}
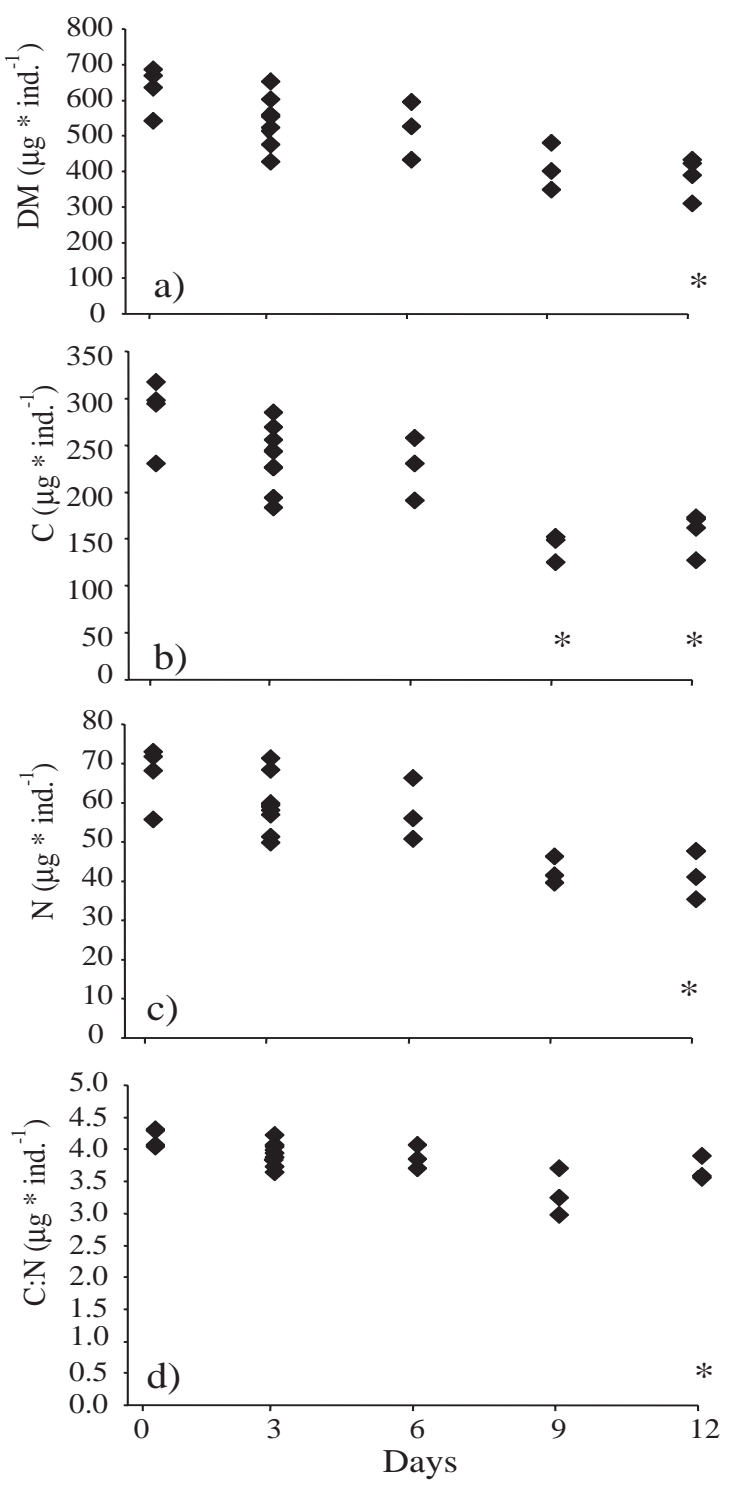

Fig. 2. Euphausia superba. Furcilia IV larvae. (a) Dry mass $(\mathrm{DM}),(\mathrm{b})$ body carbon $(\mathrm{C}),(\mathrm{c})$, body nitrogen $(\mathrm{N})$ and (d) C:N ratio of freshly caught larvae $(0 \mathrm{~d})$ and during starvation. The stars indicate significant differences to the $t_{0}$-group (freshly caught larvae, $* p<0.05$ )

loss of $0.9 \%$ in freshly caught larvae, $0.5 \%$ on sampling Day 6 , and $1.0 \%$ at the end of the starvation period. The $t_{0}$-group had an O:N ratio of 50 which decreased to 40 and remained constant in the first week of starvation, after that it decreased further to 30 and 21 (Fig. 4c). According to Ikeda \& Mitchel (1982), Mayzaud \& Conover (1988) and Ikeda et al. (2000) an O:N ratio between 3 and 16 indicates a protein-dominated metabolism, whereas a 


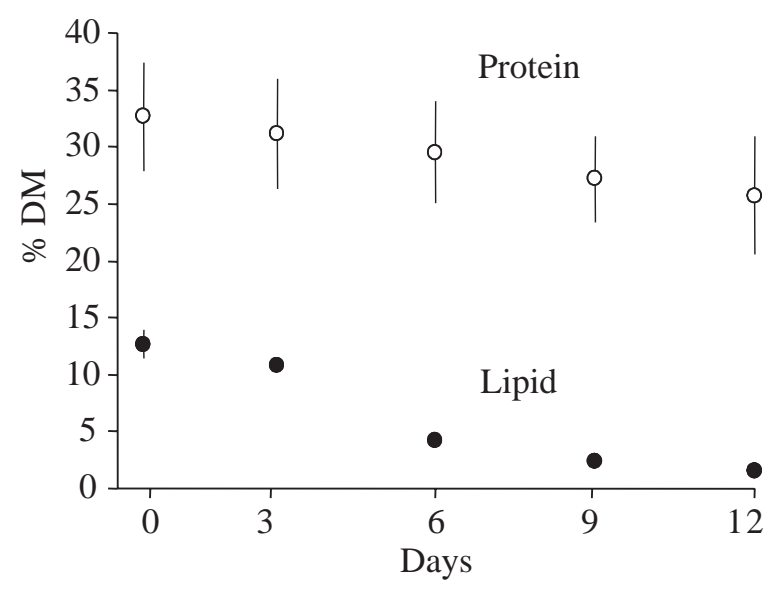

Fig. 3. Euphausia superba. Furcilia IV larvae. Total protein and lipid content in percent of dry mass (DM) of freshly caught larvae $(0 \mathrm{~d})$ and during starvation
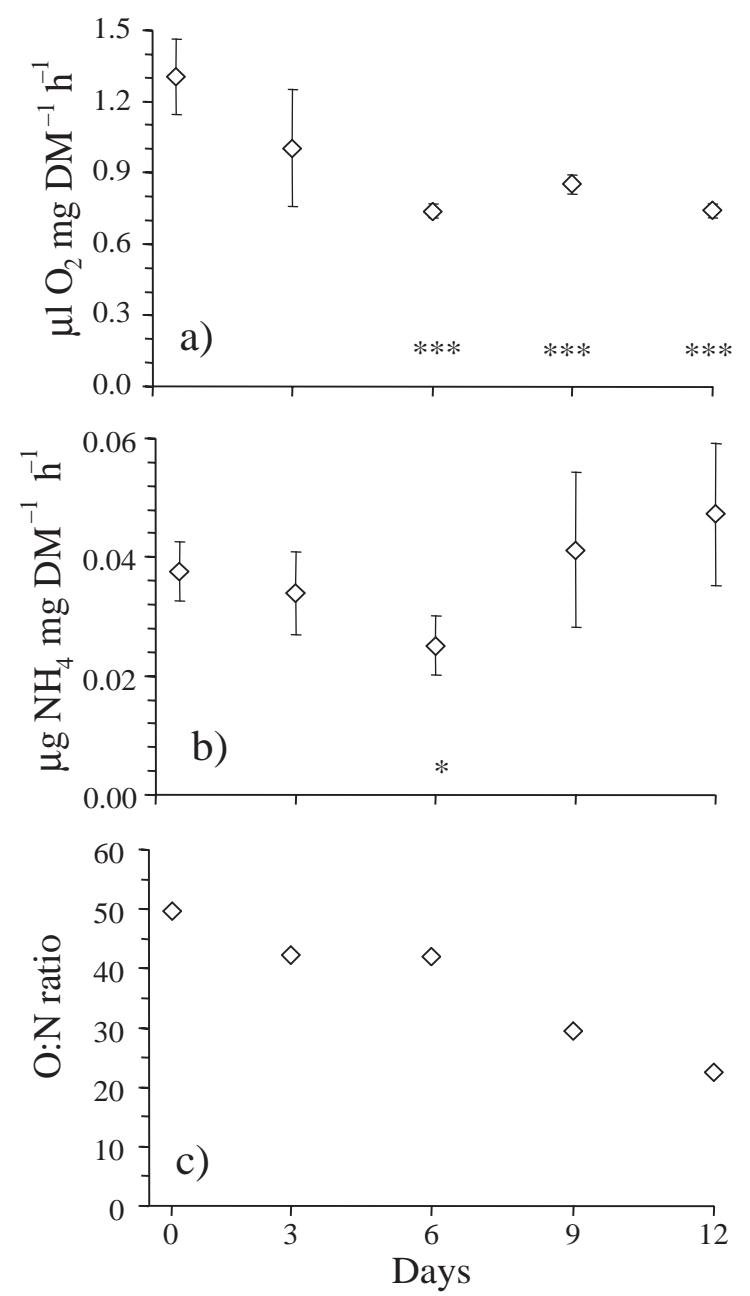

Fig. 4. Euphausia superba. Furcilia IV larvae. (a) Oxygen uptake, (b) ammonium production rates and (c) O:N ratio of freshly caught larvae $(0 \mathrm{~d})$ and during starvation. Asterisks indicate significant differences to the $t_{0}$-group (freshly caught larvae, $* \mathrm{p}<0.05, * * * \mathrm{p}<0.001)$ ratio greater than 24 shows that lipids are preferentially catabolised. Using a respiratory quotient of 0.7 (after Ikeda et al. 2000), reflecting preferential utilisation of lipids (see Fig. 4c), the oxgen uptake rates measured (see above) correspond to a $\mathrm{C}$ loss of $2.7 \%$ body $\mathrm{C} \mathrm{d}^{-1}$ in the $t_{0}$-group and in mean $2.0 \%$ body $\mathrm{C}$ $\mathrm{d}^{-1}$ after $3 \mathrm{~d}$ of starvation until the end of the experiment.

\section{DISCUSSION}

Only $12 \mathrm{~d}$ of starvation had a great effect on the biochemical composition and metabolic rates of FIV larvae. The changes in oxygen uptake and ammonium excretion are related to the use of lipid and protein reserves for survival and are reflected by changes in body composition. Below we outline the condition of FIV larvae in the field and their changes in elemental and biochemical condition and metabolic rates during a short term starvation period of $12 \mathrm{~d}$. These results will be discussed in relation to the PNR and its consequence for larval survival at the onset of winter.

Sea WiFS data have shown that bloom conditions had persisted in the study area, the eastern Bellingshausen Sea, since March 2001 (Belem 2002). This suggests that the nutritional conditions for larval krill were good. The average DM and body C content of FIV larvae suggest favourable feeding conditions (Brinton \& Townsend 1984, Daly 1990, Huntley \& Brinton 1991, Meyer et al. 2002, 2003, Pakhomov et al. 2004). However, in freshly caught larvae we measured a moderate lipid content of $13 \pm 3 \%$ of DM, compared to values found by Hagen et al. (2001) in autumn furcilia $(18 \pm 5 \%)$. At the same time, the intermoult period of freshly caught FIV larvae (15 d) suggests good nutritional condition in the study area. Huntley \& Brinton (1991) showed an IMP of $18 \mathrm{~d}$ at optimal food condi-

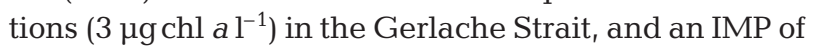
$27 \mathrm{~d}$ for furcilia in the Bransfield Strait at chl a concentration around $1 \mathrm{\mu g} \mathrm{l}^{-1}$. On the transect shown in Fig. 1 the surface chl a concentrations ranged between 1 and $2.7 \mathrm{\mu g} \mathrm{l}^{-1}$ (Brichta \& Belem 2002).

Elemental analyses are often used for indirect estimates of the proximate biochemical composition, whereas the C:N mass quotient reflects changes in the relative proportions of lipids and proteins (Anger \& Harms 1990). Both the elemental and biochemical composition measured in our study demonstrate that preferential lipids were used to fulfil energy requirements (Figs. 2b,c \& 5). After $6 \mathrm{~d}$ of starvation a shift occurred in the metabolic substrates preferentially used. The protein utilization increased, which was indicated by decreases in body protein and lipid catabolism. The increase in protein catabolism between 6 


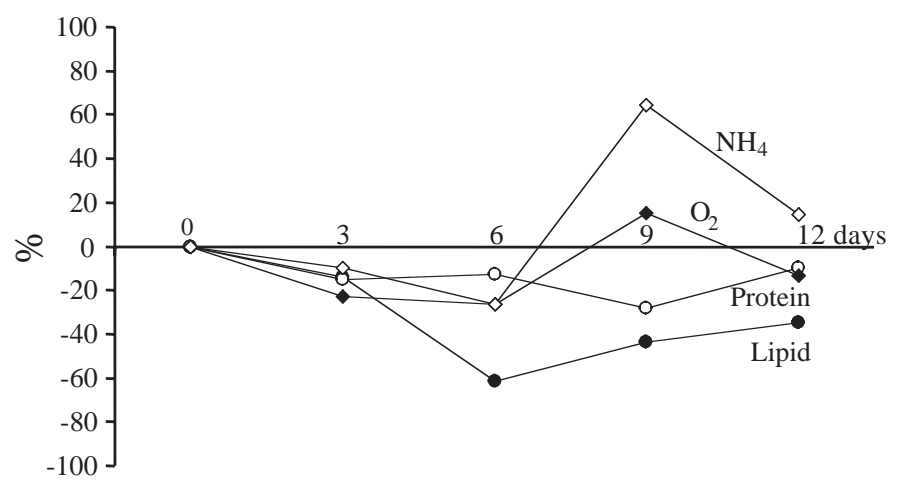

Fig. 5. Euphausia superba. Furcilia IV larvae. Percentage change in total lipids, total protein and metabolic rates from one experimental day to another during $12 \mathrm{~d}$ of starvation. $\diamond: \mathrm{NH}_{4}$-production, $\bullet$ oxygen uptake, O: body protein, $\bullet$ : body lipid

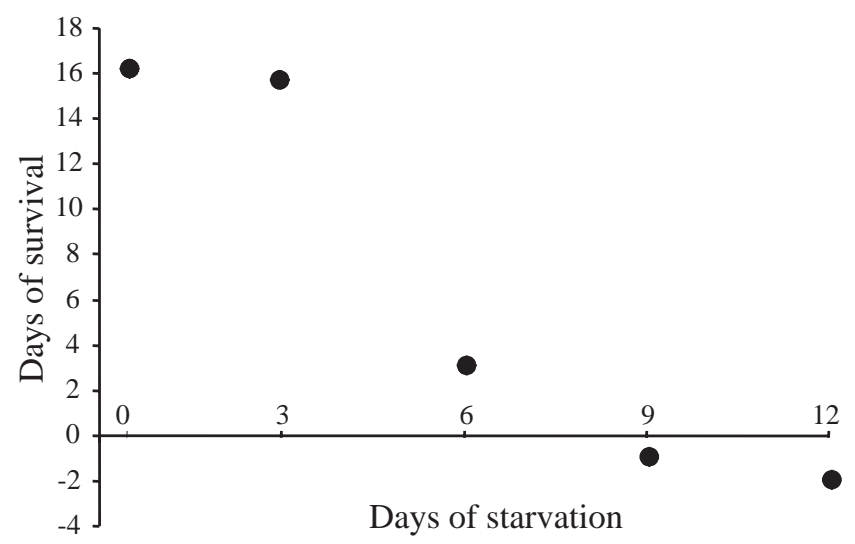

Fig. 6. Euphausia superba. Furcilia IV larvae. Calculated days of survival on the basis of body lipid content measured during the starvation experiment. For the calculation the following factors were taken into account: (1) a minimum of $3 \%$ of lipids are essential, after Hagen et al. (1996), (2) a respiratory quotient (RQ) of 0.72 was used until the 6th day of starvation (lipids were preferentially catabolised) and thereafter an RQ of 0.9 was used (a mix of protein and lipids was metabolised), after Ikeda (2000)

and $9 \mathrm{~d}$ is underlined by the increase in the ammonium production of the larvae and hence in the pattern of the $\mathrm{O}: \mathrm{N}$ ratio. During starvation the O:N ratio is clearly linked to the availability of energy reserves and the use of body protein (Mayzaud \& Conover 1988). However, in starvation experiments with the first feeding stage of krill, Calyptopis I (CI), Quetin \& Ross (1989) found no evidence of protein catabolism until the CI larvae had been starved for at least $10 \mathrm{~d}$, a time which corresponds to the PNR of the larvae.

The 2 time spans for PNR and starvation to death can differ significantly. Dawirs (1983) reported a PNR for crab larvae around $4 \mathrm{~d}$ but death did not occur until
13 d without food. According to Ross \& Quetin (1989), the PNR of Euphausia superba CI larvae is between 10 and $14 \mathrm{~d}$, about half of the $23 \mathrm{~d}$ of starvation necessary before $50 \%$ of the larvae die. The authors reported that the PNR of CI is passed when 44 to $51 \%$ of their body $\mathrm{C}$ is lost and their total lipid content is utilised. According to the initial lipid content of FIV larvae and their metabolic rates, the larvae have a survival time of $16 \mathrm{~d}$. The decrease in body $\mathrm{C}$ indicates that the FIV larvae reached their PNR after 6 to $9 \mathrm{~d}$ of starvation, because that is (after Ross \& Quetin 1989) when they lost half of their body $\mathrm{C}$ (Table 1). In regard to the decrease in body lipid and the oxygen uptake rates measured during starvation, we calculated that a PNR is reached in $\leq 6 \mathrm{~d}$ (Fig. 6). The lipid utilisation in starving furcilia seems to be a nonlinear process over time as indicated in Fig. 6. After $3 \mathrm{~d}$ of starvation, body lipid content decreased substantial to less than $3 \%$ of DM. According to Hagen et al. (1996) 3 to $5 \%$ of body lipids are essential. After the 6th day of starvation it seems that most of the larvae die, and will not be able to recover from nutritional stress; this is indicated by the negative value at Day 9 shown in Fig. 6. According to this result, the amount of body lipids in freshly caught larvae does not provide reliable information on the survival of larvae related to population success.

Our results indicate that frequent feeding is critical for larval krill survival. The larvae have to build up a sufficient lipid store to survive short-term starvation periods arising from patchiness of adequate food and/or delays in timing of sea ice formation. In the Antarctic autumn, at the onset of sea ice formation, phytoplankton biomass decreases in the water column and will be incorporated into the growing sea ice (Thomas \& Dieckmann 2003). During this phase of sea ice formation phytoplankton or ice algae are not accessible to larger grazers such as larval krill and short term periods of starvation can occur. Only later in a season will a bottom community develop in the sea ice and be utilised as an additional food source.

For a better understanding of larval survival and development, and ultimately recruitment, it is important to know when different ontogenetic stages will reach the PNR. This is more important for recruitment success than the number of days of starvation before death. The elemental and biochemical body composition determined during starvation are indirect parameters to estimate the PNR. Storch \& Anger (1983) and Vogt et al. (1985) demonstrated a more direct determination. These authors reported that the most characteristic effects of starvation in decapod larvae can be seen in ultrastructual changes of the digestive system, particularly in the $\mathrm{R}$ (resorptive)-cells. The R-cells are located in the midgut gland and are specialist cells for nutrient resorption, and are able to store lipids and 
glycogen (e.g. Al-Mohanna \& Nott 1987,1989). Vogt et al. (1985) demonstrate that even after a starvation period of 4 to $5 \mathrm{~d}$ endoplasmatic reticulum and mitochondria in the R-cells are markedly reduced. Furthermore, Anger (2001) reported that a deposition of glycogen instead of lipids occurred after subsequent feeding for decapode larvae of Hyas araneus, indicating a pathological shift in the storage metabolism of the Rcells after reaching the PNR. Although detailed study on the microscopic anatomy of the krill stomach and its development during ontogeny exists (Ullrich et al. 1991, Ullrich \& Storch 1993), histological and cytological investigations of the midgut gland of euphausiids are rare and there has been no such investigation for Euphausia superba. The importance of carbohydrate compounds (glucose, glycogen, lactic acid) to energetic processes in Antarctic krill is demonstrated in Mezykowski (1979). From the background of our results and the knowledge we have from decapods it would be worthwhile to investigate the midgut gland cells of E. superba larvae by electron-microscopy after different periods of starvation, re-feeding and in wellfed larvae, and to compare these results with investigation of larvae from the field.

The population dynamics of krill in the western Antarctic Peninsula area comprises episodic years of good recruitment, which occur once or twice per decade to maintain the krill stock (Quetin \& Ross 2003). Given the intense interannual variability in this region, both in summer phytoplankton concentration and in winter sea ice (Constable et al. 2003 and refeferences therein), environmental effects on larval survival and recruitment are likely to be of key importance. A better understanding of the mechanism underlying starvation of larvae due to delays or patchiness of food availability is therefore essential.

Acknowledgements. We thank the officers and crew of RV 'Polarstern' for their professional and friendly support during the fieldwork on the cruise ANTXVIII-5b and D. Stübing and P. Wencke for the introduction to lipid analyses. Thanks to A. Atkinson for his helpful comments on the manuscript. This work was funded by the German Federal Ministry of Education and Science (BMBF), project number 03PL025A. This is publication awi-n15044 of the Alfred Wegener Institute.

\section{LITERATURE CITED}

Al-Mohanna SY, Nott JA (1987) R-cells and the digestive cycle in Penaeus semisulcatus (Crustacea: Decapoda). Mar Biol 95:129-137

Al-Mohanna SY, Nott JA (1989) Functional cytology of the hepatopancreas of Penaeus semisulcatus (Crustacea: Decapoda) during the moult cycle. Mar Biol 101:535-544

Anger K (2001) The biology of decapode larvae. Crustacean Issues 14. AA Balkema Publishers, Lisse
Anger K, Dawirs R (1981) Influence of starvation on the larval development of Hyas araneus (Decapoda, Majidae). Helgol Meeresunters 34:287-311

Anger K, Harms J (1990) Elemental (CHN) and proximate biochemical composition of decapod crustacean larvae. Comp Biochem Physiol 97B:69-80

Atkinson A, Meyer B, Bathmann UV, Stübing D, Hagen W, Bathmann UV (2002) Feeding and energy budgets of Antarctic krill Euphausia superba at the onset of winter. II. Juveniles and adults. Limnol Oceanogr 47:953-966

Atkinson A, Siegel V, Pakhomov E, Rothery P (2004) Longterm decline in krill stock and increase in salps within the Southern Ocean. Nature 432:100-103

Båmstedt U, Gifford DJ, Irigoien X, Atkinson A, Roman M (2000) Feeding. In: Harris RP, Wiebe PH, Lenz J, Skjoldal HR, Huntley M (eds) ICES Zooplankton methodology manual. Academic Press, San Diego, CA, p 297-399

Belem A (2002) Remote sensing program during the ANTXVIII/5b cruise. Rep Polar Mar Res 407:65-67

Brichta M, Belem A (2002) Chlorophyll-a particulate organic carbon/nitrogen (POC/N) and biogenic silica (BSi) distribution. Rep Pol Mar Res 407:61-65

Brinton E, Townsend AW (1984) Regional relationships between development and growth in larvae of Antarctic krill, Euphausia superba, from field samples. J Crustac Biol 4 (spec no1):224-246

Constable AJ, Nicol S, Strutton PG (2003) Southern Ocean productivity in relation to spatial and temporal variation in the physical environment. J Geophys Res 108, C4, 8079: $6,1-6,21$

Daly KL (1990) Overwintering development, growth and feeding of larval Euphausia superba in the Antarctic marginal ice zone. Limnol Oceanogr 35:1564-1576

Dawirs R (1983) Respiration, energy balance and development during growth and starvation of Carcinus maenas L. larvae (Decapoda: Portunidae). J Exp Mar Biol Ecol 69: $105-128$

Fraser FC (1936) On the development and distribution of the young stages of krill (Euphausia superba). Discov Rep 14: $1-192$

Frazer TK, Quetin LB, Ross RM (2002) Energetic demands of larval krill, Euphausia superba, in winter. J Exp Mar Biol Ecol 277:157-171

Frost BW (1972) Effects of size and concentration of food particles on the feeding behavior of the marine planktonic copepod Calanus pacificus. Limnol Oceanogr 17:805-815

Hagen W (2000) Lipids. In: Harris RP, Wiebe PH, Lenz J, Skjodal HR, Huntley M (eds) ICES zooplankton methodology manual. Academic Press, San Diego, CA, p 113-119

Hagen W, Van Vleet ES, Kattner G (1996) Seasonal lipid storage as overwintering strategy of Antarctic krill. Mar Ecol Prog Ser 134:85-89

Hagen W, Kattner G, Terbrüggen A, Van Vleet ES (2001) Lipid metabolism of the Antarctic krill Euphausia superba and its ecological implications. Mar Biol 139:95-104

Hopkins TL, Lancraft TM, Torres JJ, Donnelly J (1993) Community structure and trophic ecology of zooplankton in the Scotia Sea marginal ice zone in winter (1988). Deep-Sea Res 40:81-105

Huntley M, Brinton E (1991) Mesoscale variation in growth and early development of Euphausia superba Dana in the western Bransfield Strait region. Deep-Sea Res 38: 1213-1240

Ikeda T, Dixon P (1982) Body shrinkage as a possible overwintering mechanism of the Antarctic krill, Euphausia superba Dana. J Exp Mar Biol Ecol 62:143-151

Ikeda T, Mitchell (1982) Oxygen uptake, ammonium excre- 
tion and phosphate excretion by krill and other Antarctic zooplankton in relation to their body size and chemical composition. Mar Biol 71:283-298

Ikeda T, Torres JJ, Hernández-León S, Geiger SP (2000) Metabolism. In: Harris RP, Wiebe PH, Lenz J, Skjodal HR, Huntley M (eds) ICES zooplankton methodology manual. Academic Press, San Diego, CA, p 455-532

Kawaguchi K, Ishikawa S, Matsuda O (1986) The overwintering strategy of Antarctic krill (Euphausia superba Dana) under the coastal fast ice off the Ongul Islands in LützowHolm Bay, Antarctica. Mem Nat Inst Polar Res, Spec Iss 44: 67-85

Lowry OH, Rosebrough NJ, Farr AL, Randall RJ (1951) Protein measurement with the Folin Phenol reagent. J Biol Chem 193:265-275

Mayzaud P, Conover RJ (1988) O:N atomic ratio as a tool to describe zooplankton metabolism. Mar Ecol Prog Ser 45: 289-302

Meyer B, Atkinson A, Stübing D, Oettl B, Hagen W, Bathmann UV (2002) Feeding and energy budgets of Antarctic krill Euphausia superba at the onset of winter. I. Furcilia III larvae. Limnol Oceanogr 47:943-952

Meyer B, Atkinson A, Blume B, Bathmann U (2003) Feeding and energy budgets of larval Antarctic krill Euphausia superba in summer. Mar Ecol Prog Ser 257:167-178

Mezykowski T (1979) Diurnal rhythms in metabolism of carbohydrate substrates in the Antarctic krill, Euphausia superba Dana. Ekol Pol 27:497-519

Nicol S (2000) Understanding krill growth and aging: the contribution of experimental studies. Can J Fish Aquat Sci 57: 168-177

Nicol S, Stolp M, Cochran T, Geijsel P, Marshall J (1992) Growth and shrinkage of Antarctic krill Euphausia superba Dana from the Indian sector of the Southern Ocean during summer. Mar Ecol Prog Ser 89:175-181

Pakhomov E, Atkinson A, Meyer B, Oettl B, Bathmann U (2004). Daily rations and growth of larval krill Euphausia superba in the Eastern Bellingshausen Sea during austral autumn. Deep-Sea Res II 51:2185-2198

Quetin LB, Ross RM (1991) Behavioural and physiological characteristics of the Antarctic krill, Euphausia superba. Am Zool 31:49-63

Quetin LB, Ross RM (2003) Episodic recruitment in Antarctic krill Euphausia superba in the Palmer LTER study region. Mar Ecol Prog Ser 259:185-200

Quetin LB, Ross RM, Frazer TK, Haberman KL (1996) Factors affecting distribution and abundance of zooplankton, with

Editorial responsibility: Otto Kinne (Editor-in-Chief), Oldendorf/Luhe, Germany an emphasis on Antarctic Krill, Euphausia superba. Ant Res Ser 70:357-371

Quetin LB, Ross RM, Frazer TK, Amsler MO, Wyatt-Evens C, Oakes SA (2003) Growth of larval krill, Euphausia superba, in fall and winter west of the Antarctic Peninsula. Mar Biol 143:833-843

Ross RM, Quetin LB (1989) Energetic cost to develop to the first feeding stage of Euphausia superba Dana and the effect of delays in food availability. J Exp Mar Biol Ecol 133:103-127

Siegel V, Loeb V (1995) Recruitment of Antarctic krill Euphausia superba and possible causes for its variability. Mar Ecol Prog Ser 123:45-56

Smetacek V, Sarek R, Nöthig EM (1990) Seasonal and regional variation in the pelagical and its relationship to the life history cycle of krill. In: Kerry KR, Hempel G (eds) Antarctic ecosystems: ecological change and conservation. Springer, Berlin, Heidelberg, New York, p 103-114

Solorzano L (1969) Determination of ammonia in natural waters by the phenolhypochlorite method. Limnol Oceanogr 14:799-801

Storch V, Anger K (1983) Influence of starvation and feeding on the hepatopancreas of larval Hyas araneus (decapoda, Majidae). Helgol Meeresunters 36:67-75

Strass V, Borth H, Cisewski B, Rabe B, Radke C, Rinas K (2002) Hydrographic conditions of the Eastern Bellingshausen Sea ecosystem during Austral autumn, 2001. Rep Polar Mar Res 407:11-16

Thomas DN (ed), Dieckmann GS (2003) Sea Ice-an introduction to its physics, biology, chemistry and geology. Blackwell Scientific, Oxford

Ullrich B, Storch V (1993) Development of the stomach in Euphausia superba Dana (Euphausiacea). J Crustac Biol 13:423-431

Ullrich B, Storch V, Marschall HP (1991) Microscopic anatomy, functional morphology, and ultrastucture of the stomach of Euphausia superba Dana (Crustacea, Eupausiacea). Polar Biol 11:203-211

Vogt G, Storch V, Quinitio ET, Pascual FP (1985) Midgut gland as monitor organ for the nutritional value of diets in Penaeus monodon (Decapoda). Aquaculture 48:1-12

Wright SW, Jeffrey SW, Mantoura RFC (1997) Evaluation of methods and solvents for pigments extraction. In: Jeffrey SW, Mantoura RFC, Wright SW (eds) Phytoplankton pigments in oceanography. UNESCO Publishing, Paris, p 261-282

Submitted: September 14, 2004; Accepted: January 27, 2005 Proofs received from author: April 15, 2005 